\title{
Air-based Mechanical Stimulation Controls Plant Height of Ornamental Plants and Vegetable Crops under Greenhouse Conditions
}

\author{
Marc-André Sparke ${ }^{1}$, Achim Wegscheider ${ }^{2}$, \\ Patrick Winterhagen ${ }^{3}$, Ute Ruttensperger ${ }^{4}$, Martin Hegele ${ }^{1}$, \\ and Jens Norbert Wünsche ${ }^{1}$
}

ADDITIONAL INDEX WORDS. automated stimulus application, innovation, mechanosensing, organic crop production, technology, thigmomorphogenesis

SumMARY. Mechanical stimulation to produce stable and high-quality crops under greenhouse conditions is a promising alternative to chemical growth retardants. However, plant tissue damage and the lack of full automatization have been major constraints for large-scale applications. We demonstrate the potential of automated, touch-less, directed air stream application systems to control the plant height and appearance of bellflower (Campanula 'Merrybell'), creeping inchplant (Callisia repens), and tomato (Solanum lycopersicum 'Romello'). Plants were cultivated under greenhouse conditions and exposed to regulated air stream stimuli by three different prototype systems. Air stream stimuli of all three prototype systems significantly reduced plant height of all three plant species. Bellflower plants showed a reduction of $24 \%$ and tomato plants showed reductions of $26 \%$ to $36 \%$ compared with the respective control plants. The degree of height growth inhibition in tomato was shown to be predominantly influenced by the stimulus intensity. An air pressure prototype system was successfully implemented in a horticultural company and the height of creeping inchplant could be sufficiently reduced by $20 \%$, on average, throughout 1 year of the experiment compared with untreated controls. Overall, no plant tissue damage of plants treated with the air stream was visible, and no difference in the number of flowers of the bellflower plants treated with the air stream and of the untreated controls was observed.

$\mathrm{M}$ orphogenetic plant responses to mechanical stimulation (MS) have been the subject of several research projects over the past decades. The altered growth behavior induced by MS was first described by Jaffe (1973) as thigmomorphogenesis. The growth-inhibiting effect caused by a direct physical impact by touching, rubbing, or brushing is mainly used to improve plant quality criteria such as stability and appearance, thereby increasing the market value of greenhouse-raised plants (Garner and Björkman, 1996; Jaffe and Forbes, 1993; Latimer, 1998; Latimer and Beverly, 1993; Latimer and Thomas, 1991). Moreover, through the application of mechanical treatments, the obtained compact and stable plants, which are tougher and sturdier because of their increased shear strength and increased modulus of rupture (Heuchert and Mitchell, 1983), are better able to withstand potential impacts during handling, transplanting, transport, and shipping (Latimer, 1998; Latimer and Beverly, 1993; Samimy, 1993). Underlying complex mechanosensing mechanisms are responsible for specific endogenous plant processes such as gibberellic acid (GA) biosynthesis inhibition or calcium $\left(\mathrm{Ca}^{2+}\right)$ signaling responses (Chehab et al., 2009; Sparke and Wünsche, 2020), which frequently result in anatomical and morphological plant adaptation.

Considering the worldwide growing and competitive horticultural market, producers of high-quality plants are realizing the necessity to establish an efficient and economic production regime to l) maximize productivity per unit area, 2) effectively use transportation capacity, 3) minimize losses attributable to damage by transportation, and 4) fulfill the market requirements. To meet these numerous challenges, horticulturists have to implement production processes that require a high level of skillful crop management. During greenhouse cultivation, for example, excessive stem elongation can be controlled by regulating the water and nutrient supplies and controlling temperature conditions (Garner and Björkman, 1996). Nevertheless, during ornamental plant production, the application of plant growth regulators (PGRs) is still the most commonly used tool for achieving an effective reduction in plant height (Latimer, 1992; Morel et al., 2012). However, increased public concern and governmental restrictions have limited the use of chemicals in plant production. Additionally, the legally defined use of PGRs often leads to some constraints in the production regime of the company because, in many cases, re-entry into the greenhouse section is not allowed for at least $24 \mathrm{~h}$ after PGR application, and, if necessary, re-entry is only allowed with protective clothing. Consequently, the growing demand for sustainable production systems requires the development and practical implementation of alternative crop management strategies, such as organic cultivation methods, that might have the potential to increase profitability (Raviv, 2010). In this context, the use of thigmomorphogenic effects can be a promising application technology in large-scale horticultural greenhouse production as an alternative to PGRs. Furthermore, it was previously demonstrated that various mechanical

\begin{tabular}{llll}
\hline $\begin{array}{l}\text { Units } \\
\text { To convert U.S. to SI, } \\
\text { multiply by }\end{array}$ & U.S. unit & SI unit & $\begin{array}{l}\text { To convert SI to U.S., } \\
\text { multiply by }\end{array}$ \\
\hline 0.3048 & $\mathrm{ft}$ & $\mathrm{m}$ & 3.2808 \\
0.0929 & $\mathrm{ft}^{2}$ & $\mathrm{~m}^{2}$ & 10.7639 \\
3.7854 & gal & $\mathrm{L}$ & 0.2642 \\
2.54 & inch(es) & $\mathrm{cm}$ & 0.3937 \\
25.4 & inch(es) & $\mathrm{mm}$ & 0.0394 \\
16.3871 & inch & $\mathrm{cm}$ & 0.0610 \\
0.4470 & $\mathrm{mph}$ & $\mathrm{m} \cdot \mathrm{s}^{-1}$ & 2.2369 \\
0.001 & $\mathrm{ppm}$ & $\mathrm{g} \cdot \mathrm{L}^{-1}$ & 1000 \\
0.001 & $\mathrm{ppm}$ & $\mathrm{mL} \cdot \mathrm{L}^{-1}$ & 1000 \\
$\left({ }^{\circ} \mathrm{F}-32\right) \div 1.8$ & ${ }^{\circ} \mathrm{F}$ & ${ }^{\circ} \mathrm{C}$ & $\left({ }^{\circ} \mathrm{C} \times 1.8\right)+32$
\end{tabular}


treatments reduced plant height to a similar extent as PGR applications (Adler and Wilcox, 1987; Biddington and Dearman, 1987; Latimer, 1991).

Beyl and Mitchell (1977) invented an automated system that shakes and touches plants simultaneously to control plant growth, but their device was unsuitable for largescale crop production. Further technical approaches to control plant shoot elongation involved brushing plants manually with cardboard (Latimer, 1990) or paper sheets (Biddington and Dearman, 1985). These mechanical treatments could only be applied at irregular intensities to a limited number of plants, and the high humidity conditions inside greenhouses led to upwelling and wear-out of the brushing material. Latimer and Thomas (1991) used a moving polyvinylchloride (PVC) pipe for successfully reducing the average stem length and leaf area of tomato (Solanum lycopersicum) greenhouse plants. However, the friction of the PVC on the plant surface caused undesirable damage to the leaf tissue, particularly when plants were turgid. Alternatively, a smooth bar made of wood or steel, which was vertically adjustable to account for time-dependent plant height differences, reduced the growth of several plant species (Baden and Latimer, 1992; Latimer, 1991; Latimer et al., 1991). Koch et al. (2011) further improved the brushing application by using a fleece

Received for publication 8 Dec. 2020. Accepted for publication 9 Mar. 2021

Published online 2 June 2021

${ }^{1}$ Department of Crop Sciences, Institute of Crop Physiology of Specialty Crops, Emil-Wolff-Straße 25, 70599 Stuttgart, Germany

${ }^{2}$ Department of Natural and Environmental Scien ces, Institute of Environmental Sciences, Fortstrasse 7, 76829 Landau, Germany

${ }^{3}$ Center for Rural Services Rheinpfalz, Institute of Phytomedicine, Breitenweg 71, 67435 Neustadt, Germany

${ }^{4}$ State Horticulture College and Research Institute, Diebsweg 2, Heidelberg, 69123, Germany

This project was funded by the Federal Office for Agriculture and Food (BLE)

We thank the engineering companies Knecht GmbH and Raith $\mathrm{Tec}$ for the construction of the air stream modules, and the horticultural company Fleischle Gartenbau GbR for the practical implementation.

M.H. and J.N.W. are deceased.

M.-A.S. is the corresponding author. E-mail: marc. sparke@uni-hohenheim.de

This is an open access article distributed under the CC BY-NC-ND license (https://creativecommons. org/licenses/by-nc-nd/4.0/).

https://doi.org/10.21273/HORTTECH04773-20 material and demonstrated a significant reduction in internode length for several organically cultivated herbs. However, plant quality was frequently diminished through the repeated direct physical impact, resulting in damage to the shoot tips, leaves, and petals (Garner and Björkman, 1997; Garner and Langton, 1997; Johjima et al., 1992; Koch et al., 2011; Latimer, 1991; Latimer and Beverly, 1993). The extent of the reported plant damage appears to be dependent on plant species, cultivar, season (Garner and Björkman, 1997; Garner and Langton, 1997; Latimer and Beverly, 1993); these factors render the development of a suitable application system difficult. To our knowledge, an efficient and reliable mechanical application system that inhibits plant growth and concomitantly maintains plant quality is not yet available for horticultural crop cultivation under greenhouse conditions. In response to this production constraint, the objectives of this study were to evaluate three air stream application modules that apply a controlled and directed air stimulus to plants sustainably cultivated under greenhouse conditions. During this study, the height growth of 'Merrybell' bellflower ( Campanula), a favored ornamental plant, 'Romello' tomato, which has frequently been investigated for reactions to cultivation conditions, and growing

mechanical stimulation, and creeping inchplant (Callisia repens), a main crop of a horticulture company used for pet feed production, were studied under experimental and commercial greenhouse conditions.

\section{Materials and methods}

CONSTRUCTION OF THE AIR PRESSURE MODULE. The single technical components of the air pressure module are presented in a schematic illustration (Fig. 1). A metal frame, originally conceptualized to support an irrigation system for plant production under greenhouse conditions, served as the carrier unit for all technical components of the air pressure module. A blank holder was mounted onto the front side of the metal frame and supported two individual polyethylene pipes, which separated the incoming air stream of the air inlet tube. Both pipes were equipped with a magnetic valve and a manometer. The magnetic valves facilitated either the opening or closure of the respective pipe, and the manometers allowed for monitoring of the air pressure. Two individual air distribution tubes were attached to each polyethylene pipe to further distribute the air stream to a pipe either at the front or at the rear of a substructure. The substructure was mounted underneath the metal frame by vertically fixed steel struts to

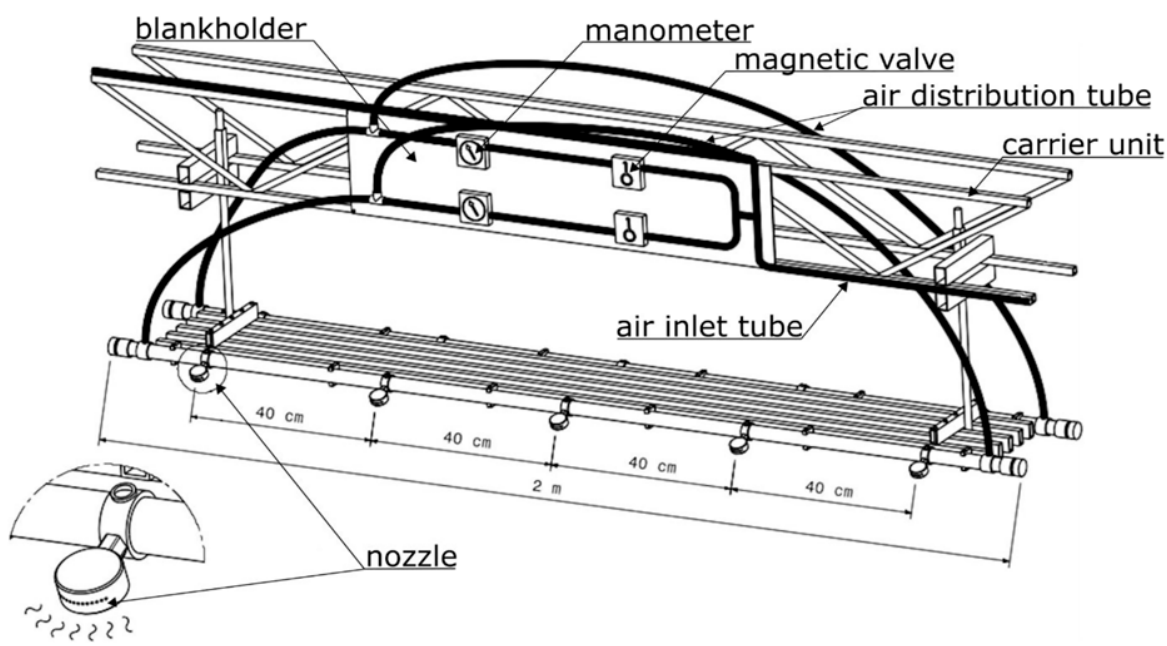

Fig. 1. Three-dimensional representation of the air pressure system installed in the greenhouse at the State Horticulture College and Research Institute (Heidelberg, Germany) and a close-up of a single nozzle. A moveable metal frame serves as carrier unit for the entire construction. The air stream is conveyed from the air inlet tube to two polyethylene pipes that are attached to a blankholder. Each pipe is equipped with a magnetic valve and a manometer. The air stream is further distributed via air distribution tubes to pipes clipped onto the front and rear of a substructure. $1 \mathrm{~cm}=0.3937$ inch. 
both sides. The struts could be manually moved upward and downward along the vertical axis to adjust the height from $0 \mathrm{~cm}$ (minimum linkage extension) to $65 \mathrm{~cm}$ (maximum linkage extension). The entire length of the substructure was $2 \mathrm{~m}$, and it comprised five consecutively arranged hollow aluminum bars. Therefore, low weight, stability, and reduced vibrations and oscillation during system movement could be achieved. The pipes, which were clipped at the front and rear of the substructure, were each equipped with five stainless steel nozzles (Lechler, Metzingen, Germany; Knecht, Metzingen, Germany) spaced $0.4 \mathrm{~m}$ apart that served as air stream outlets. Each nozzle had 13 drill holes with different diameters. The diameter of the two outer holes on either side was $0.9 \mathrm{~cm}$. The adjacent three holes on both sides had a diameter of $0.6 \mathrm{~cm}$, and the three center holes were $0.4 \mathrm{~cm}$ wide. The angle of incidence of the air stream could be adjusted manually from horizontal to vertical $\left(0^{\circ}-90^{\circ}\right)$ by turning the respective pipe at the front or rear of the substructure.

Functional PRINCIPLE. The air stream that is conveyed to the air pressure module and subsequently applied to plants was generated by a stationary compressor with a downstream connected pressure regulator. The entire system was fully automated by an electrical control system (IB Ebner, Konstanz, Germany). The metal frame was suspended on a longitudinal guide rail that used an electric motor to facilitate its forward and backward movements across the entire greenhouse complex. Start and reversal positions of the frame were determined by magnets, which were placed at the appropriate position on the guide rail. As soon as a magnet was reached, an electric signal initiated either a reverse movement or a stop impulse of the frame. However, the entire system could be configured with additional options.

The air stream was applied while the frame was driving toward the reversal position, and then back to its start position or only in one of the two directions. Magnetic switches placed at determined positions along the guide rail induced an electric signal, which triggered the activation or deactivation of the air stream; therefore, the air stream could be adjusted for treating specific application schemedependent greenhouse areas. The driving speed of the frame ranged from 1.5 to $18 \mathrm{~m} \cdot \mathrm{min}^{-1}$, and the number of transits could be adjusted from 0.5 to 10 after a start pulse at preset time intervals.

CONSTRUCTION AND FUNCTION OF THE CENTRIfugal Fan SYSTEM. Two additional prototype systems were tested in a greenhouse facility at the University of Hohenheim, Stuttgart, Germany. The air stream was generated by a $0.37-\mathrm{kW}$ centrifugal fan (VBL8; Air Control Industries, Axminster, England) mounted to a vertical aluminum bar as the carrier unit (Fig. 2, left). The bar was connected to a wheel drive powered by an electric motor (IB Ebner) and ran across a horizontally positioned guide rail (Fig. 2, right). The flow rate of the air stream could be adjusted by a throttle valve set at an angle from $0^{\circ}$ (fully open) to $90^{\circ}$ (fully closed). The air stream was then split by a Y-connector and passed through two arms of 7.6$\mathrm{cm}$-diameter flexible ducting, which were connected to either the air knife or the $360^{\circ}$ rotor module. A horizontal aluminum bar that served as carrier unit for the respective module was fixed with hinges to the vertical bar and rope tensions were used to stabilize the entire system. Vertically attached linkages on either side of the horizontal bar permitted the fixation of the respective module with threaded rods on both sides.

AIR KNIFE MODULe. The air knife module (Air Control Industries) was constructed of two identical casings of anodized aluminum, which were screwed together to form a hollow

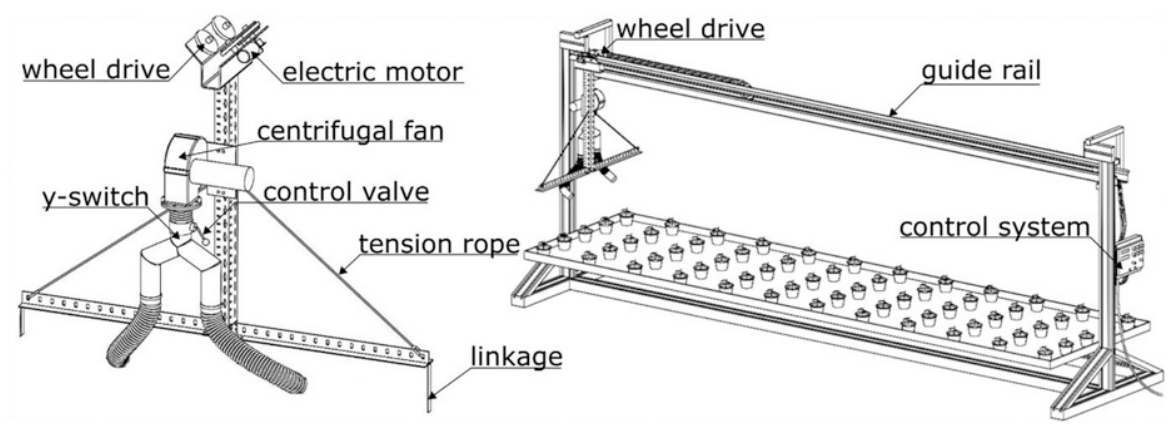

Fig. 2. Centrifugal fan system (left side) installed in the greenhouse at the University of Hohenheim (Stuttgart, Germany). A wheel drive is powered by an electric motor that facilitates the movement of the fan system across a longitudinal guide rail above the greenhouse table (right side). A vertical aluminum bar serves as the carrier unit for the centrifugal fan. The air stream is passed through flexible ducting and regulated mechanically by a control valve unit. space (Fig. 3). The inner profile of the air knife produced a continuous laminar air stream. Two air inlet holes (diameter, $76 \mathrm{~mm}$ ) were positioned at the back side of the air knife. The air outlet was an aperture slot that could be adjusted from 1 to $5 \mathrm{~mm}$ by loosening (opening) or tightening (closing) screws, thereby extending small springs inside the casing. The effective length of the air knife was $1.2 \mathrm{~m}$, and the angle of incidence of the air stream could be manually adjusted by turning the manifold from $0^{\circ}$ (vertical) to $90^{\circ}$ (horizontal) along its vertical axis. Threaded rods on each side of the module facilitated the insertion of the module into the carrier system.

$360^{\circ}$ ROTOR MODULE. The $360^{\circ}$ rotor module (Raith Tec, Ditzingen, Germany) was a hollow, rectangular, aluminum box with a volume of $\approx 1500 \mathrm{~cm}^{3}$ and an overall length of 1 $\mathrm{m}$ (Fig. 4). Two air inlet holes (76 $\mathrm{mm}$ diameter) at the back delivered the air stream to two rotating PVC tubes inserted on the bottom at $20 \mathrm{~cm}$ away from both lateral surfaces of the module. The air flow escaped the air outlet tubes as a turbulent free air stream at a fixed $20^{\circ}$ angle below to the horizontal line. The $360^{\circ}$ rotation of the tubes was facilitated by a chain drive with gear wheels $(60 \mathrm{~mm}$ diameter) mounted on the top and powered by a $12-\mathrm{W}$ electric motor (Mädler, Stuttgart, Germany) placed side of the module allowed its fixation on the carrier system. The electrical control system (IB Ebner) was identical to that described for the air pressure module. on the front. Threaded rods on each 


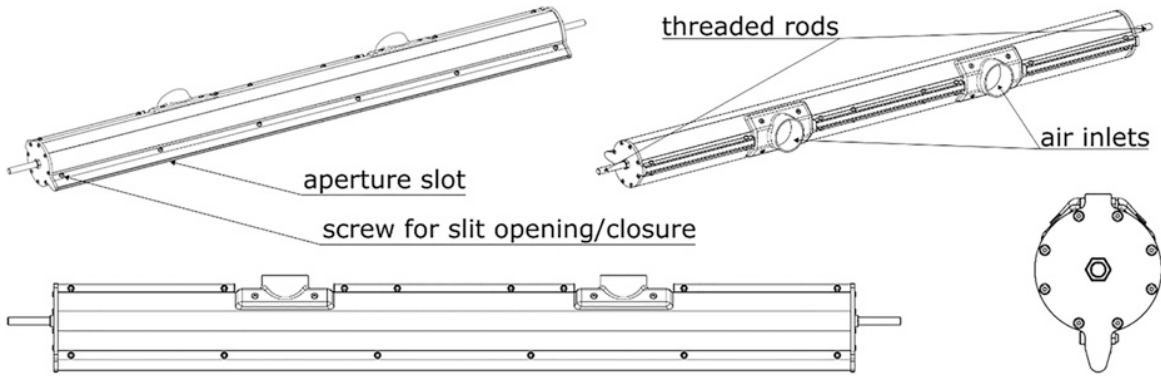

Fig. 3. Three-dimensional representation of the air knife module front and back (top) installed in the greenhouse at the University of Hohenheim (Stuttgart, Germany), and the top view and cross-section representation (bottom). Two air inlet holes are inserted on the backside and the air outlet is an aperture slot along the front. The aperture slot can be adjusted by loosening or tightening screws. Threaded rods are attached on both sides to mount the module on the carrier unit.

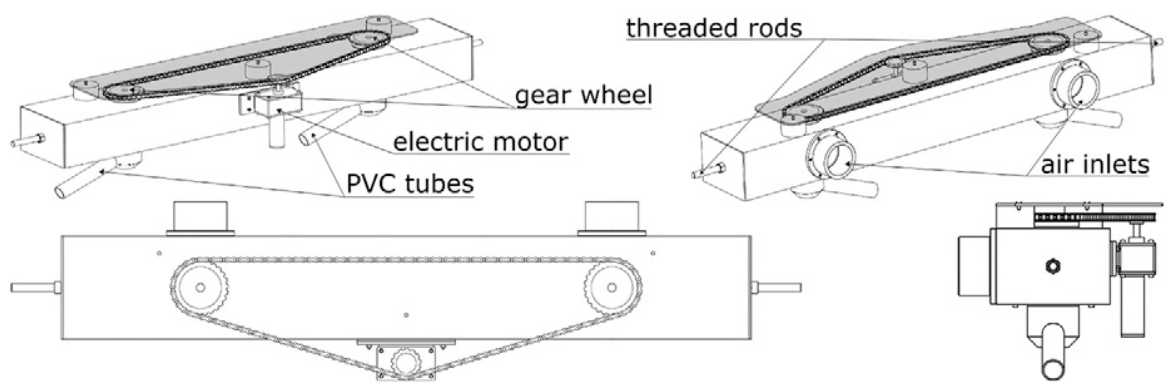

Fig. 4. Three-dimensional representation of the rotor module front and back (top) installed in the greenhouse at the University of Hohenheim (Stuttgart, Germany), and the top view and cross-section representation (bottom). Two $360^{\circ}$ rotating polyvinylchloride (PVC) tubes are inserted in the bottom of the aluminum corpus. The rotation of the tubes is caused by chain-driven gear wheels that are powered by an electric motor. Threaded rods are attached on both sides to mount the module on the carrier unit.

AIr VELOCITY MEASUREMENTS. A pocket weather meter (Kestrel 4000; PCE Deutschland, Meschede, Germany) placed on a tripod was used to determine the air velocity of the respective module. Air velocity measurements were obtained from 0 to 60 $\mathrm{cm}$ away from the air outlet at the center positions of individual nozzles of the air pressure module and the PVC tubes of the $360^{\circ}$ rotor module, respectively, as well as at five positions equally spaced along the aperture slot of the air knife module corresponding to the plant rows on the greenhouse table (five rows). Moreover, various air stream flow rates were set by adjusting the aperture slot opening width from 1 to $5 \mathrm{~mm}$ on the air knife and adjusting the throttle from $11.75^{\circ}$ (nearly closed) to $90^{\circ}$ (fully open) on the $360^{\circ}$ rotor module. The throttle on the air knife was set to $90^{\circ}$ (fully open). Measurements were recorded as soon as the fluctuations were mini$\mathrm{mal}\left( \pm 0.5 \mathrm{~m} \cdot \mathrm{s}^{-1}\right)$.

Plant material and experimental Design at the STATE Horticultural College and Research INSTITUTE. The effect of directed air stimuli applied by the air pressure system on the height growth of bellflower and tomato plants was investigated under greenhouse conditions at the State Horticultural College and Research Institute, Heidelberg, Germany. Three bellflower 'Merrybell' scions were transplanted to one plastic pot $(0.5 \mathrm{~L}$ volume) each filled with substrate [12N-6.1P-19.9K (RHP 15; Klasmann-Deilmann, Geeste, Germany)]. Bellflower plants were grown for 9 weeks during winter season (Table 1 ) under natural light conditions with average photosynthetic active radiation $(P A R)$ of $\approx 350 \mu \mathrm{mol} \cdot \mathrm{m}^{-2} \cdot \mathrm{s}^{-1}$ and day/night air temperatures of 20/ $16^{\circ} \mathrm{C}$. During week 10 , flowering was induced by long days ( $14 \mathrm{~h} / 10 \mathrm{~h}$ day/ night) with high-pressure sodium bulbs (SONT Agro $400 \mathrm{~W}$; Philips, Amsterdam, the Netherlands). Irrigation was performed by table flooding with $\mathrm{l} \mathrm{g} \cdot \mathrm{L}^{-1}$ fertilizer $[18 \mathrm{~N}-4.8 \mathrm{P}-$ 14.9K (Universol blue; ICL Specialty Fertilizers, Tel Aviv, Israel)]. Tomato seeds were sown in 104-cell trays and grown for 3 weeks during the spring season (Table 1). Thereafter, seedlings were transplanted to plastic pots (volume, 2 L) filled with substrate [12N-6.1P-19.9K (Seedlingsubstrat, Klasmann-Deilmann)]. Irrigation was performed by table flooding with 5 $\mathrm{mL} \cdot \mathrm{L}^{-1}$ liquid fertilizer $[7 \mathrm{~N}-0.9 \mathrm{P}-$ 2.5K (Organic Plant Feed; Plant Health Cure, Oisterwijk, The Netherlands)]. Tomato plants were grown under natural light conditions with an average $P A R$ of $850 \mu \mathrm{mol} \cdot \mathrm{m}^{-2} \cdot \mathrm{s}^{-1}$. Relative humidity was $60 \%$ and day/ night air temperatures were $20 / 16^{\circ} \mathrm{C}$.

The bellflower experiment was set up as a one-factorial (air stream) design with two blocks, each with two greenhouse tables that were longitudinally separated in one air stream and one control area, respectively. Air stimuli were applied by one air pressure module in each block. Eight hundred bellflower plants were uniformly arranged across the four tables with plants on two table halves regularly treated with a directed air stream of a defined air velocity for 10 weeks; the plants on the other two table halves served as untreated controls. The planting density accounted for 20 plants $/ \mathrm{m}^{2}$. The experiment with tomato was conducted with only one air pressure module and comprised 76 plants for each table half with a planting density of 10 plants $/ \mathrm{m}^{2}$. Throughout the 2 -week tomato experiment, the distance between the air outlet of the individual nozzles and plant tips was maintained at $\approx 15 \mathrm{~cm}$.

Bellflower and tomato were evaluated for plant height. The bellflower plant height was defined as the length of the longest upright standing shoot, and tomato plant height was determined by measuring the height from the pot rim to the tip of the main shoot apex. On each table half, 12 bellflower plants that were 10 weeks old and four tomato plants that were 5 weeks old 
Table 1. Relevant dates of experiments involving air-based mechanical stimulation control of plant height conducted at the State Horticultural College and Research Institute (Heidelberg, Germany) and the University of Hohenheim (Stuttgart, Germany).

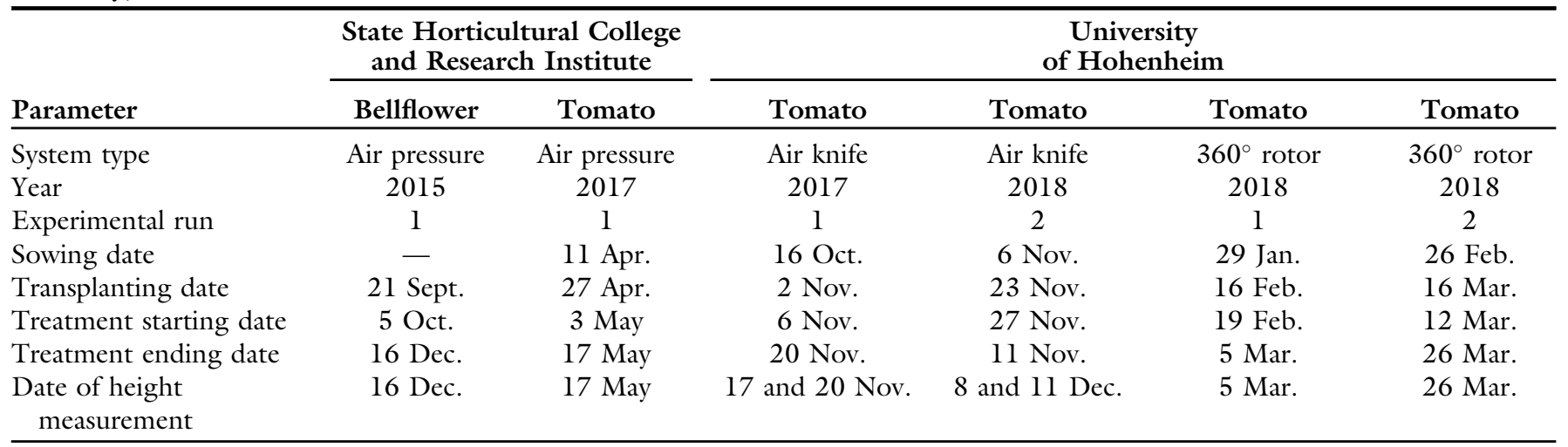

were randomly selected for plant height measurements, respectively.

Throughout the experiment, only the nozzles at the front of the modules were activated, and air pressure was generated by two scroll compressors (SF-4 FF; Atlas Copro, Essen, Germany). Details regarding relevant dates related to the plant cultivation procedure are shown in Table 1, and additional functional settings of the experiments with the air pressure module are shown in Table 2.

Plant material and experimenTAL DESIGN AT UNIVERSITY OF HoHENHEIM. The effect of directed air stimuli applied by the air knife and the $360^{\circ}$ rotor module on the height growth of tomato plants was investigated under greenhouse conditions at the University of Hohenheim. Tomato seeds were sown in 104-cell trays with one seed per plug and grown for 3 weeks during the winter season
(Table 1). Thereafter, seedlings were transplanted to plastic pots (volume, $0.5 \mathrm{~L})$ filled with substrate [12N6.1P-19.9K (Substrat 5, KlasmannDeilmann)]. Throughout both experimental runs, plants were grown under natural light conditions with an average $P A R$ of $250 \mu \mathrm{mol} \cdot \mathrm{m}^{-2} \cdot \mathrm{s}^{-1}$. Plants were watered manually every second day with $80 \mathrm{~mL}$ tap water and 2.34 $\mathrm{g} \cdot \mathrm{L}^{-1}$ water-soluble fertilizer $[16 \mathrm{~N}-$ 2.6P-21.6K (FERTY 2 MEGA; Hauert, Grossaffoltern, Switzerland)]. The day/night air temperatures were set to $20 / 16^{\circ} \mathrm{C}$, and relative humidity ranged from $50 \%$ to $70 \%$. The carrier unit (Fig. 2, right) was placed above the greenhouse table $(3 \times 1.2 \mathrm{~m})$ that was transversely separated as a control half and air stream-treated half. Each experiment was repeated twice with both treatments randomly placed on the greenhouse table halves. The passage of the modules commenced first at the table end of the control and then at the air stream area. Thirty tomato seedlings were evenly distributed on each table area with a planting density of 16 plants $/ \mathrm{m}^{2}$. When the respective air stream module reached the magnet placed at the center position on the longitudinal guiderail, the air stream was initiated or stopped. A polystyrene board was placed between the control and air stream areas to avoid any air stream stimulation of control plants. Plant height was determined for all 60 plants on days 11 and 14 after treatment initiation during the air knife experiment and on day 14 during the $360^{\circ}$ rotor module experiment.

The throttle valve for adjusting the air stream flow rate was at $60^{\circ}$, and it was fully opened for the $360^{\circ}$ rotor module. The aperture slot on the air knife module was set to $5 \mathrm{~mm}$. Because the angle of the air jet incidence was set to $10^{\circ}$ from the vertical

Table 2. Air supply settings of various mechanical stimulation experiments on ornamental and vegetable plants under greenhouse conditions at the State Horticultural College and Research Institute (Heidelberg, Germany), the University of Hohenheim (Stuttgart, Germany), and a commercial horticulture company (Vaihingen Ensingen, Germany).

\begin{tabular}{|c|c|c|c|c|c|}
\hline \multirow[b]{2}{*}{ Parameter } & \multicolumn{2}{|c|}{$\begin{array}{l}\text { State Horticultural College } \\
\text { and Research Institute }\end{array}$} & \multicolumn{2}{|c|}{$\begin{array}{c}\text { University } \\
\text { of Hohenheim }\end{array}$} & \multirow{2}{*}{$\begin{array}{c}\begin{array}{c}\text { Commercial } \\
\text { company }\end{array} \\
\text { Creeping inchplant }\end{array}$} \\
\hline & Bellflower & Tomato & Tomato & Tomato & \\
\hline Driving velocity $\left(\mathrm{m} \cdot \mathrm{min}^{-1}\right)^{\mathrm{z}}$ & 1.5 & 1.5 & 1.5 & 1.5 & 10 \\
\hline First start impulse (HR) & 0800 & 0700 & 0800 & 0800 & 0700 \\
\hline Start impulses (no./d) & 6 & 4 & 8 & 8 & 8 \\
\hline Time between start impulses (min) & 45 & 45 & 45 & 45 & 15 \\
\hline Angle of incidence ${ }^{\mathrm{w}}$ & $60^{\circ}$ & $60^{\circ}$ & $10^{\circ}$ & $70^{\circ}$ & $0^{\circ}$ \\
\hline
\end{tabular}

${ }^{\mathrm{z}} 1 \mathrm{~m}=3.2808 \mathrm{ft}$.

${ }^{\mathrm{y}}$ Air stream application during back and forth movement.

${ }^{\mathrm{x}}$ Air stream application only during forth movement.

wFrom the vertical line. 
position, there was a gradually increased stimulus duration along the air stream axis on the greenhouse table. This effect was not observed in the rotor module because of the $360^{\circ}$ rotation of the air outlet tubes. At the beginning of the experiments, the distance between the air outlet and plant tip was $\approx 60 \mathrm{~cm}$. As the plants grew taller over the experimental period of 2 weeks and the distance between the air outlet and plant tip was not adjusted, increasingly stronger stimulation intensities were perceived by the plants. Details regarding relevant dates related to the plant cultivation procedure are shown in Table 1. Additional functional settings used during the experiments with both modules are shown in Table 2.

To evaluate the effect of air velocity on plant height, plants were replaced with the pocket meter at various positions on the table on day 11 after treatment initiation with the air knife module. Measurements were obtained at 2-s intervals using the data logging function of the gadget, thereby allowing a record of the maximum air velocity, the stimulus duration, and the cumulative air velocity at each single plant position. The cumulative air velocity was calculated from the sum of the air velocity measurements during one transit. In other words, during system movement, the air stream gradually approached plants positioned in backrows. Those plants were exposed to longer air stimulation and cumulative air velocity compared with plants that were positioned closer to the starting position of the air knife module.

Commercial application. The effect of directed air stimuli applied by the air pressure system on the height growth of creeping inchplant was also tested under commercial conditions at a local horticulture company (Fleischle, Vaihingen Ensingen, Germany). Plant management was entirely performed by the company owner. Three scions were transplanted in plastic pots (volume, $0.5 \mathrm{~L}$ ) filled with substrate (14N-7.0P-14.9K; CL T; Einheitserdewerke Patzer; Sinntal-Altengronau, Germany). The air pressure module, which was adjusted to the greenhouse dimension of the company, was attached to the crossbeam of the irrigation system as described previously. The module was $13 \mathrm{~m}$ long and equipped with 18 air outlet nozzles that were arranged at uniform intervals on the front of the PVC tube. The air pressure was generated by a piston compressor (SAZ 1011; Mahle, Stuttgart, Germany) and a screw compressor (RSC 40; Renner, Güglingen, Germany); both were fueled by a 250$\mathrm{L}$ diesel tank outside the greenhouse complex. Five consecutive experimental sets (1-5) were conducted over the course of 1 year, and plant height was evaluated as described for the bellflower experiment. One greenhouse table was separated longitudinally into halves, with one half assigned to the air stream area and the other half assigned to the control area. In each experimental set, 10 plants of the air stream area and the control area were randomly selected for measurements of plant height. Details of the air pressure settings are provided in Table 2 .

Data analysis. F-tests were performed with the PROC MIXED statement (SAS version 9.4; SAS Institute, Cary, NC) for all experiments, with the significance level set to $P \leq 0.05$. For the tomato experiment with the air knife module, records of air velocity and plant height on day 11 after treatment initiation were analyzed using the following multiple linear regression model:

$$
y=B_{0}+B_{1} x_{1}+B_{2} x_{2}+B_{3} x_{3}
$$

where $y$ is the dependent variable (plant height), $B_{0}$ is the intercept, $x_{1}$ is the air velocity sum, $x_{2}$ is the air velocity duration, and $x_{3}$ is the maximum air velocity. $B_{1}, B_{2}$, and $B_{3}$ are the estimated parameters for the $x$ variables. Variables that were found to insignificantly contribute to the response variable were removed.

\section{Results}

AIR VELOCITY MEASUREMENTS. During experiments performed at the State Horticultural College and Research Institute, the average maximal air velocity at the nozzle outlets of the air pressure module after pressure equalization was obtained was $\approx 13$ $\mathrm{m} \cdot \mathrm{s}^{-1}$ (Fig. 5A). The air velocity of the turbulent air jet followed an exponential decay curve with increasing measurement distance from the air outlet, decreasing to $3 \mathrm{~m} \cdot \mathrm{s}^{-1}$ at $30 \mathrm{~cm}$ and to $\approx 1 \mathrm{~m} \cdot \mathrm{s}^{-1}$ at $60 \mathrm{~cm}$. The air velocity perceived at the plant apical meristem was $\approx 4 \mathrm{~m} \cdot \mathrm{s}^{-1}$, which was assured by a daily adjustment of the distance to $15 \mathrm{~cm}$ between the air outlet and plant tip.

During experiments at the University of Hohenheim, the maximal air outlet velocity at the aperture slot of the air knife module was $\approx 12$ $\mathrm{m} \cdot \mathrm{s}^{-1}$ for the opening widths of 5,4 , and $3 \mathrm{~mm}$; however, the maximal air outlet velocities at the aperture slot of the air knife module were $\approx 10 \mathrm{~m} \cdot \mathrm{s}^{-1}$ and $\approx 7 \mathrm{~m} \cdot \mathrm{s}^{-1}$ for the opening widths of $2 \mathrm{~mm}$ and $1 \mathrm{~mm}$, respectively (Fig. 5B). Air velocity of the laminar air flow decreased exponentially with the measurement distance from the air outlet, reaching $\approx 3 \mathrm{~m} \cdot \mathrm{s}^{-1}$ at a distance of $60 \mathrm{~cm}$, regardless of the slot opening width. The exponential decay of air velocity with distance from the air outlet was less pronounced when the opening width was reduced. The air outlet velocity of the $360^{\circ}$ rotor module strongly depended on the air flow that was regulated by the throttle $\left(11.75^{\circ}-90^{\circ}\right)$. When the throttle was fully open $\left(90^{\circ}\right)$, the maximal air velocity was $17 \mathrm{~m} \cdot \mathrm{s}^{-1}$, and it gradually decreased to $5 \mathrm{~m} \cdot \mathrm{s}^{-1}$ when it was almost closed $\left(11.75^{\circ}\right)$ (Fig. 5C). The air velocity decreased exponentially for all throttle opening angles, reaching $\approx 3.5 \mathrm{~m} \cdot \mathrm{s}^{-1}$ when fully open and $0.5 \mathrm{~m} \cdot \mathrm{s}^{-1}$ at the lowest angle.

After system activation of the air pressure module during experiments at the State Horticultural College and Research Institute, the time required to obtain a uniform air velocity was $\approx 250$ $s$ (Fig. 6A and B). The third nozzle of the air pressure module 1 (Fig. 6A) reached an air velocity of $\approx 16 \mathrm{~m} \cdot \mathrm{s}^{-1}$ compared with $13 \mathrm{~m} \cdot \mathrm{s}^{-1}$ reached with the other four nozzles. In contrast, the sixth nozzle of air pressure module 2 (Fig. 6B) reached an air velocity of $\approx 7.5 \mathrm{~m} \cdot \mathrm{s}^{-1}$ compared with $\approx 13 \mathrm{~m} \cdot \mathrm{s}^{-1}$ reached with the other four nozzles.

Air velocity measurements at five equally spaced positions along the air knife aperture slot with an opening width of $5 \mathrm{~mm}$ revealed considerable fluctuation (Fig. 7A). Directly at the air outlet, the maximum air velocity was measured at position 4 as 15 $\mathrm{m} \cdot \mathrm{s}^{-1}$, and the minimum air velocity was measured at position 5 as $9 \mathrm{~m} \cdot \mathrm{s}^{-1}$. The fluctuation of the air velocity among the five measurement positions was gradually reduced with increased distance. The air velocity at position 3 was consistently the highest, ranging between $10 \mathrm{~m} \cdot \mathrm{s}^{-1}$ (distance, $10 \mathrm{~cm}$ ) 


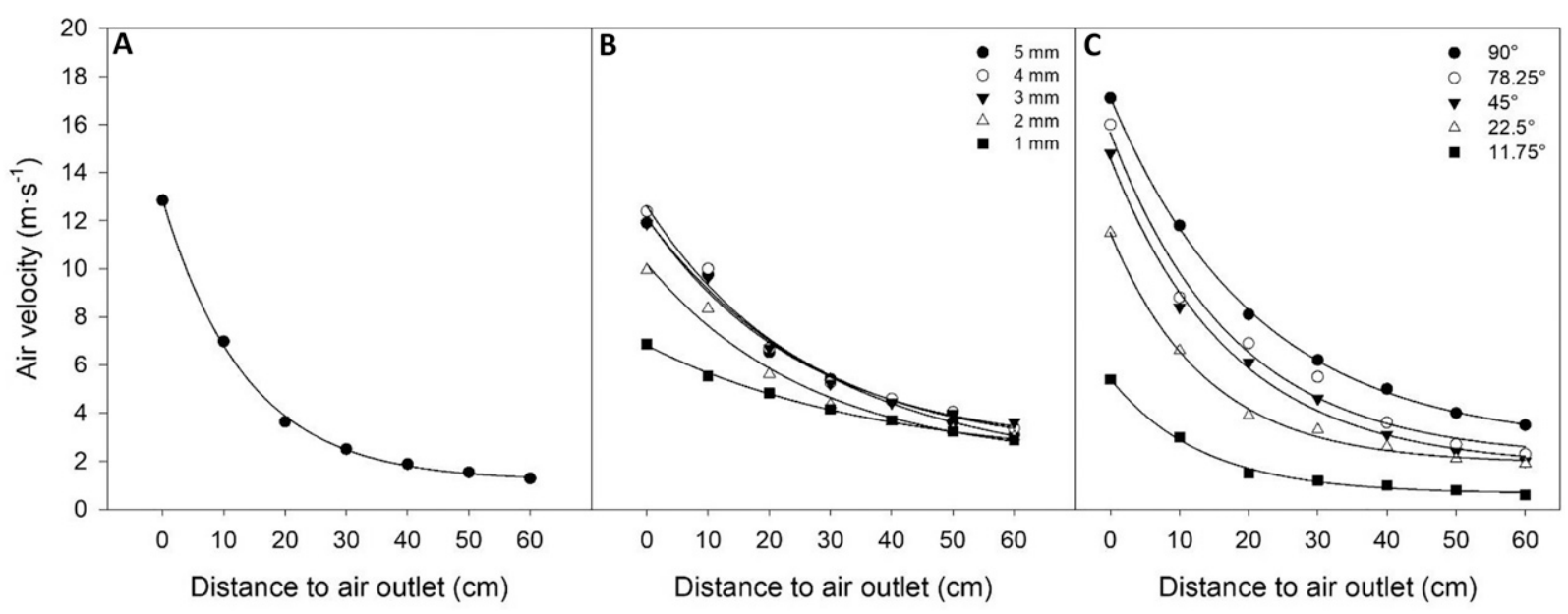

Fig. 5. Air velocities of the air pressure module implemented in the greenhouse at the State Horticulture College and Research Institute, Heidelberg, Germany (A), the air knife module with opening width of the aperture slot from 1 to 5 mm (B), the $360^{\circ}$ rotor module with throttle adjustment from $11.75^{\circ}$ to $90^{\circ}$ implemented in the greenhouse at the University of Hohenheim, Stuttgart, Germany (C) at measurement distances of 0 to $60 \mathrm{~cm}$ from the air outlet. The relationship between the measurement distance from the air outlet and air velocity was significant $(P<0.0001)$ for all air systems and various slot opening widths of the air knife module and throttle opening angles for the experiment with the $360^{\circ}$ rotor module. The $R^{2}$ value of the regression line between the measurement distance and air velocity for the air pressure module was 0.99 , and it ranged between 0.98 and 0.99 for the air knife and the $360^{\circ}$ rotor module at various slot opening widths and throttle opening angles. $1 \mathrm{~cm}=0.3937 \mathrm{inch} ; 1 \mathrm{~mm}=0.0394 \mathrm{inch} ; 1 \mathrm{~m} \cdot \mathrm{s}^{-1}=2.2369 \mathrm{mph}$.

and $4 \mathrm{~m} \cdot \mathrm{s}^{-1}$ (distance, $60 \mathrm{~cm}$ ). When the aperture slot was reduced to $1 \mathrm{~mm}$ (Fig. 7B), less air velocity fluctuation among the measurement positions was observed. Again, there tended to be a gradual decrease in the air velocity at all positions with increased measurement distance from the air outlet. The highest air velocities were measured at distances of $0 \mathrm{~cm}$ and $10 \mathrm{~cm}$ from the air outlet, with maximum values of
8 and $6 \mathrm{~m} \cdot \mathrm{s}^{-1}$, respectively, observed at position 1 .

Plant growth Responses of BELLFLOWER. Before treatment initiation, bellflower plants had an average plant height of $3.9 \mathrm{~cm}$. Air stimuli applied by the air pressure module at 80 transits per day throughout a growth period of 10 weeks induced a significant $24 \%$ reduction $(P<0.0001)$ in bellflower plant height compared with untreated control plants (Fig. 8). Consequently, air stream-treated bellflower plants showed a denser growth type with less elongated side shoots compared with untreated control plants (Fig. 9B). Moreover, no difference in the number of flowers was observed for air stream-treated and control plants.

Plant growth Response of TOMATO. A comparison of the three modules regarding their efficacy for

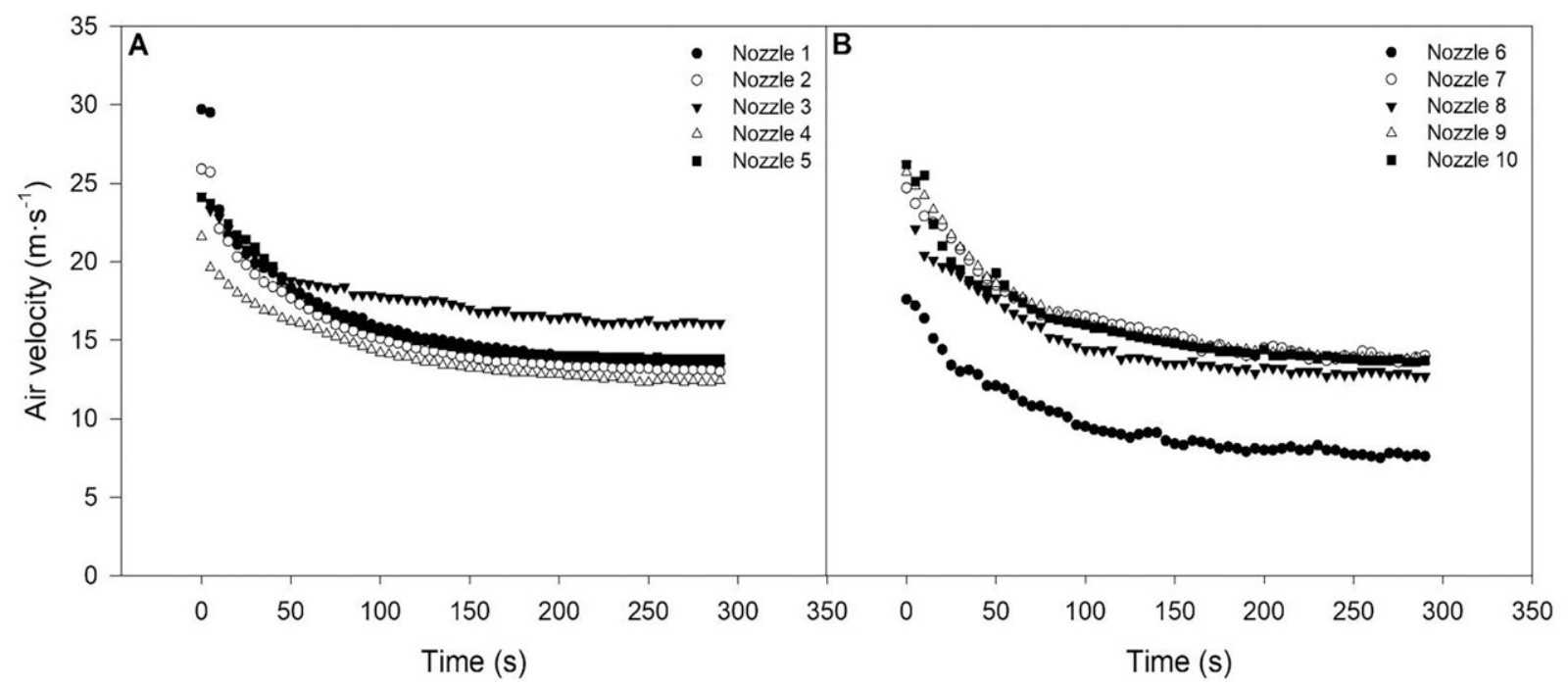

Fig. 6. Air velocity at the center position directly at the air outlet of the individual nozzles (1-10) of air pressure module 1 (A) and air pressure module 2 (B) for a time period of $300 \mathrm{~s}$ implemented in the greenhouse at the State Horticultural College and Research Institute (Heidelberg, Germany). $1 \mathrm{~m}=3.2808 \mathrm{ft} ; 1 \mathrm{~m} \cdot \mathrm{s}^{-1}=2.2369 \mathrm{mph}$. 


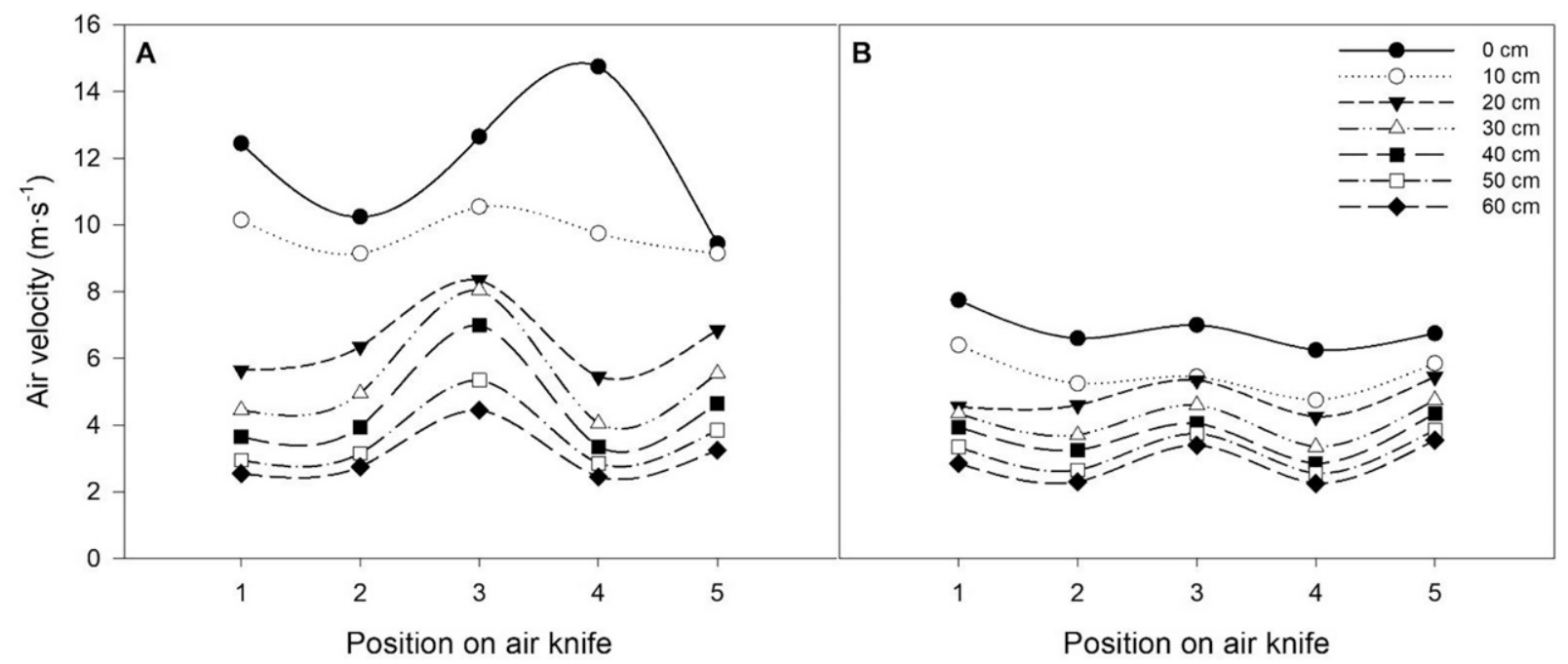

Fig. 7. Air velocity with the fully open throttle valve $\left(90^{\circ}\right)$ at five positions along the length of the air knife module implemented in the greenhouse at the University of Hohenheim (Stuttgart, Germany) with measurement distances of 0 to 60 $\mathrm{cm}$ from the aperture slot with opening widths of $5 \mathrm{~mm}(\mathrm{~A})$ and $1 \mathrm{~mm}(\mathrm{~B}) .1 \mathrm{~cm}=0.3937 \mathrm{inch} ; 1 \mathrm{~mm}=0.0394 \mathrm{inch} ; 1$ $\mathrm{m} \cdot \mathrm{s}^{-1}=2.2369 \mathrm{mph}$.

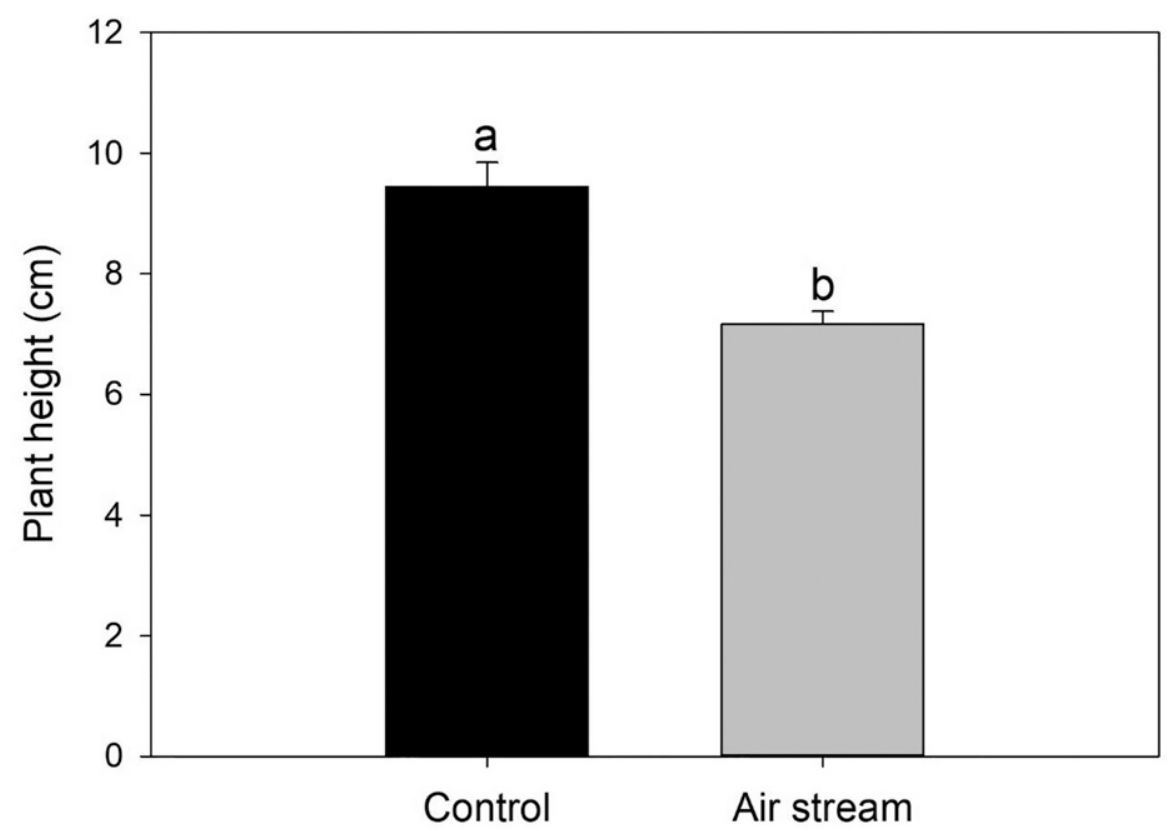

Fig. 8. Mean plant height of bellflower control plants and air stream-treated plants of the air pressure module at the State Horticultural College and Research Institute (Heidelberg, Germany). Vertical bars indicate SE $(n=24)$. Bars with different letters indicate significant difference at $P \leq 0.05 .1 \mathrm{~cm}=0.3937$ inch.

reducing tomato plant height with 80 transits per day over the course of a growth period of 2 weeks is shown in Table 3. Before treatment initiation, tomato plants had an average plant height of $2.2 \mathrm{~cm}$. Air stimuli applied by the air pressure system significantly reduced plant height $(P<0.0001)$ by $36 \%$ compared with untreated control plants (Fig. 9A). In contrast, air stimuli applied by the air knife resulted in a significant reduction $(P<0.0001)$ in plant height $(26 \%)$ compared with control plants. Air stimuli applied by the $360^{\circ}$ rotor system also induced a significant reduction $(P<0.0001)$ in plant height $(33 \%)$.

The height of air knife-treated tomato plants was highly variable $(8-16 \mathrm{~cm})$. Because of the $10^{\circ}$ inclination of the air knife, tomato plants were exposed to increasingly higher stimulus durations ranging from 10 $\mathrm{s}$ to $\approx 40 \mathrm{~s}$ per transit along the air stream axis. The maximum air velocity ranged from 1 to $4 \mathrm{~m} \cdot \mathrm{s}^{-1}$; consequently, the cumulative air velocity range was between 5 and $30 \mathrm{~m} \cdot \mathrm{s}^{-1}$ per transit. The multiple regression analysis revealed the following significant $(P<0.0001)$ regression model:

$$
y=16.62-0.01 x_{1}+0.01 x_{2}-2.1 x_{3}
$$

Maximum air velocity was the variable that best explained the variability in plant height (Fig. 10C); no significant effects of stimulus duration (Fig. 10A) and cumulative air velocity (Fig. 10B) on plant height were observed. The removal of insignificant variables resulted in the following linear equation model:

$$
y=-2.16 x+16.8
$$

where $y$ is the response variable (plant height) and $x$ the maximum air velocity.

CREePING INCHPLANT EXPERIMENT. The evaluation of the air pressure system in a commercial setting showed that the applied air stream stimuli significantly reduced plant height of creeping inchplant (Fig. 11). Plant appearance was markedly improved, as indicated by a reduction in plant height with fewer elongated shoots (Fig. 9C). The efficiency of air stream stimuli to regulate plant height growth of creeping inchplant was dependent on the season; the experiments performed during fall and 


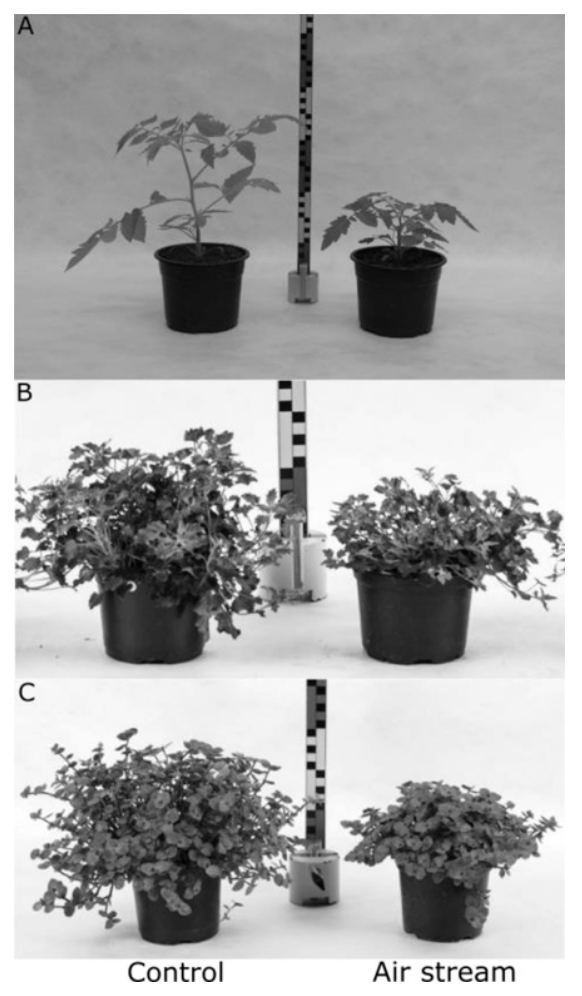

Fig. 9. Plant appearance of tomato (A) and bellflower (B) at 2 weeks and 10 weeks after air stream initiation with the air pressure module and untreated control plants at the State Horticulture College and Research Institute (Heidelberg, Germany). Plant appearance of regularly air stream-treated creeping inchplant by the air pressure module and untreated control plants $(C)$ of experimental run three at a local horticulture company (Vaihingen Ensingen, Germany).

winter (sets 4 and 5 ) induced a stronger reduction in height growth $(22 \%$ to $32 \%$ ) than those performed during spring and summer (sets 1, 2, and 3), with an average reduction in plant height of $15 \%$ compared with untreated controls.

Table 3. Mean plant height of tomato after $14 \mathrm{~d}$ of air stream treatment with 80 transits per day using the various air supply modules at the State Horticultural College and Research Institute (Heidelberg, Germany) or the University of Hohenheim (Stuttgart, Germany); $\mathbf{n}=\mathbf{8}$ for air pressure module; $\mathbf{n}=\mathbf{6 0}$ for air knife and $360^{\circ}$ rotor module.

\begin{tabular}{lrcc}
\hline & \multicolumn{2}{c}{ Plant ht $[\text { mean } \pm \text { SD }(\mathrm{cm})]^{\mathrm{z}}$} & Reduction \\
\cline { 2 - 4 } Treatment & \multicolumn{1}{c}{ Control } & Air stream-stimulated & \begin{tabular}{c} 
(\%) \\
\hline Air pressure
\end{tabular} $22.5 \pm 1.5 \mathrm{a}^{\mathrm{y}}$ \\
Air knife & $22 \pm 2.8 \mathrm{a}$ & $14.3 \pm 1.8 \mathrm{~b}$ & 36 \\
$360^{\circ}$ rotor & $21.8 \pm 1.9 \mathrm{a}$ & $16.2 \pm 2.9 \mathrm{~b}$ & 26 \\
\hline
\end{tabular}

${ }^{\mathrm{z}} 1 \mathrm{~cm}=0.3937$ inch.

${ }^{\mathrm{y}}$ Means followed by different letters indicate significant difference between control and air stream-stimulated plants at $P \leq 0.05$.

\section{Discussion}

Air module Development. One of the first automated brushing modules for mechanical plant growth regulation was implemented at the State Horticultural College and Research Institute in 2009 (Regnant et al., 2009) and 2010 (Koch et al., 2011). Previously proposed system configurations were created by using the boom watering systems as the carrier mer and Thomas, 1991). Additionally, the reported problem of plant damage caused by direct physical contact between plant tissue and fleece material was addressed, and a system equipped with plastic spray nozzles (Type LU-120-03, Lechler) was used for air stream application. This earlier version was continually modified and finally resulted in the current air pressure system (Fig. 1).

Plastic spray nozzles were replaced by custom-built stainless-steel nozzles (Lechler and Knecht), with each containing 13 outlet holes with increased diameters from the inner toward the outer drill holes, resulting in more uniform air distribution across the plant stand. However, at $\approx 20 \mathrm{~cm}$ from the center position of one nozzle, the air streams of the two adjacent nozzles were likely to interfere, thereby causing omni-directed air currents and subsequently resulting in variable air velocities across the plant stand.

Because of these findings, an additional prototype system was developed and implemented on a small scale for greenhouse applications at the University of Hohenheim. The air knife module was implemented to create a more uniform air curtain across the plant stand to induce consistent height growth reduction. However, the air velocity was highly variable

Horllechnology • August 2021 31(4) along the $1.2-\mathrm{m}$ aperture slot and strongly dependent on the opening width (Fig. 7). Consequently, a third prototype module was developed that generated a cone-shaped air jet through two $360^{\circ}$ rotating PVC tubes, thus permitting multiple plant stimuli during one transit. Moreover, when the throttle was fully opened, the $360^{\circ}$ rotor module produced higher air velocities than the air knife module. Moreover, it could cover a greater greenhouse table area and fulfill the basic requirements for homogenous air distribution across the plant stand. For all these reasons, the rotating air application module seemed to be best for air stimulus applications. Air-based stimulation for inducing thigmomorphogenetic effects does not cause plant and product quality-related damage such as that reported previously for direct touch stimulus systems (Koch et al., 2011; Latimer, 1994; Latimer and Beverly, 1993).

AIr VELOCITY PERFormANCE. Three nozzle types were tested for air velocity along their air stream axis (Fig. 5). Custom-built flat spray nozzles, circular PVC nozzles, and continuous slit nozzles showed a gradual decrease in air velocity with increased measurement distance from the air outlet, thereby creating an inverse proportional dependency. The gradual reduction in air velocity is related to friction losses occurring between the air stream and surrounding air mass and to an increase in stream mass transport as the range occupied by the air jet increases with distance $(\mathrm{Za}$ wadzki et al., 2010). The flat spray nozzles and circular PVC tube nozzles produced turbulent free air streams comparable to air jets of circular axialsymmetric nozzles (Zawadzki et al., 2010), and the pattern of air velocity loss based on the distance from the air outlet was similar. The greater air outlet velocities of the circular PVC nozzles with fully opened throttles were lost by the stronger decay in air velocity. The profile inside the plenum chamber of the air knife corpus generates a laminar air jet that enters the surrounding media (Trancossi, 2011) and maintains greater, less decaying air velocities along the air stream axis compared with air jets produced by circular nozzle types.

Individual nozzles on the air pressure module 2 tended to have slightly greater fluctuations in air velocity until

. 


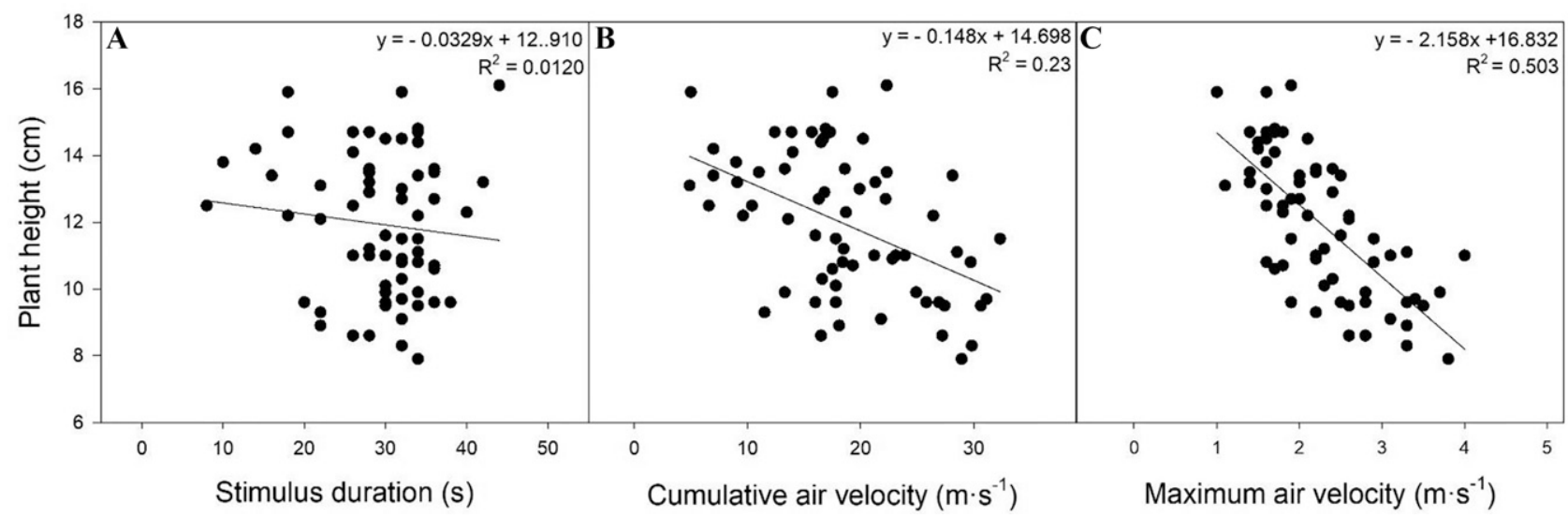

Fig. 10. Relationships between stimulus duration (A), cumulative air velocity (B), and maximum air velocity (C) and tomato plant height $11 \mathrm{~d}$ after air stream initiation with the air knife module with the throttle valve set at $60^{\circ}$ at the University of Hohenheim (Stuttgart, Germany). $P=0.7812,0.84$, and 0.0003 for the effects of cumulative air velocity, stimulus duration, and maximum air velocity on plant height, respectively. $1 \mathrm{~cm}=0.3937 \mathrm{inch} ; 1 \mathrm{~m} \cdot \mathrm{s}^{-1}=2.2369 \mathrm{mph}$.

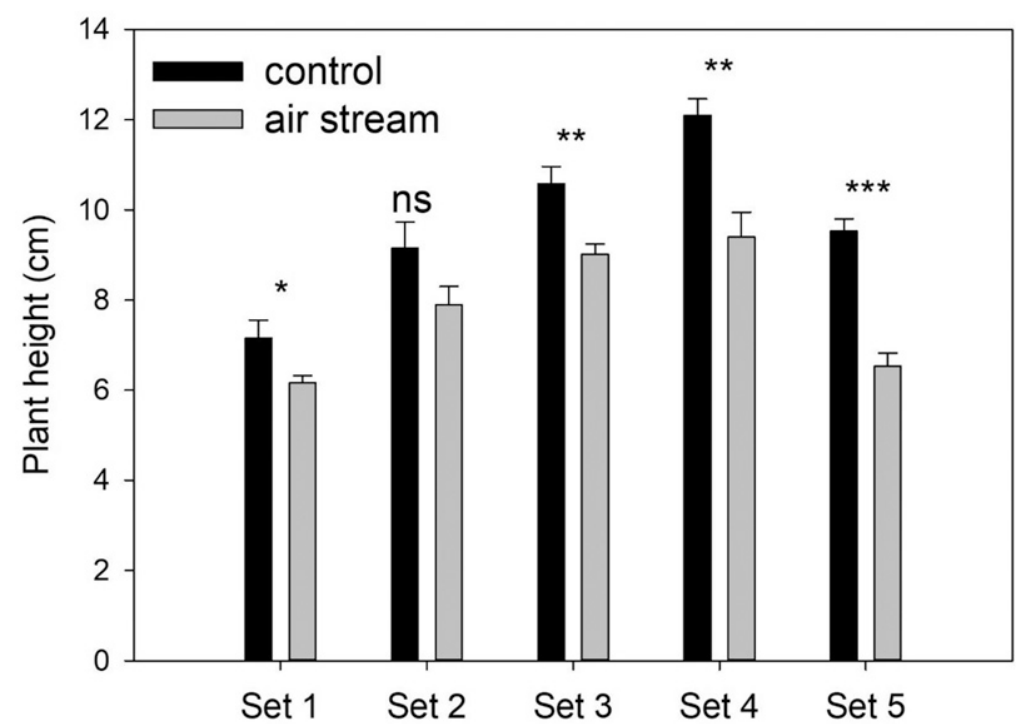

Fig. 11. Mean plant height of the control and air stream-treated creeping inchplants of five consecutive experimental sets within 1 year at a local horticulture company (Vaihingen Ensingen, Germany). Vertical bars indicate SE $(\mathbf{n}=10) . \mathbf{n s}, *, * *$, and $* * *$ represent nonsignificance or significance at $P \leq \mathbf{0 . 0 5}$, $P \leq 0.01$, or $P \leq 0.001$, respectively. $1 \mathrm{~cm}=0.3937$ inch.

a stable air outlet velocity was reached compared with the nozzles of module 1 (Fig. 6). This was presumably because of module 2 receiving the incoming air stream from the generator. Moreover, the air velocities of individual nozzles were not uniform, likely because of small air leakages in the plastic air tubes.

Plant growth Response OF BELLFLOWER. It was shown that the air pressure module was suitable for controlling the plant height of bellflower when applied 120 times per day (Fig. $8)$. Experiments that tested growth responses by mechanical stimulation using burlap material showed a maximum reduction in plant height of ornamentals of $25 \%$ for aster (Callistephus chinensis), 19\% for dusty miller (Senecio bicolor), and 34\% for petunia (Petunia) (Autio et al., 1994). Garner and Langton (1997) used polythene material or plastic netting to apply touch stimuli but could not regulate the plant growth of geranium (Geranium) and impatiens ( Impatiens holstii) without causing significant plant damage; however, the brushing effects induced $17 \%$ to $30 \%$ reductions in the petiole length in petunia and pansy (Viola tricolor)
(Garner and Langton, 1997). The results are of the same magnitude as the data shown in this study, indicating that touchless air stream stimulation has effects similar to those of treatments based on direct physical contact to induce plant movement and, subsequently, thigmomorphogenesis. Furthermore, Autio et al. (1994) found significant effects of daily brushing duration on the degree of plant height reduction of dusty miller and petunia, which is a thigmomorphogenetic response that was not seen for aster. There was no effect of various air stimulus durations on the degree of height reduction for tomato (Fig. 10A); however, this relationship for bellflower remains unclear. Bellflower plants located in rows between two adjacent nozzles showed a less stunted height growth compared with those in rows directly underneath a nozzle, indicating that stimulation intensity might have had a role.

Plant growth Response of toMATO. It was shown that defined and directed air jets applied as either a laminar air stream or turbulent free air streams by three distinct system configurations were suitable to induce (depending on the applied stimulus intensity and the used module) $26 \%$ to $36 \%$ reductions in tomato plant height compared with untreated control plants (Table 3). The data are in agreement with the results of growth regulation experiments using other stimulation techniques and are of the same order of magnitude compared with one PGR treatment (Latimer and Beverly, 1993). For example, Schnelle et al. (1994) 
applied mechanical stimuli to tomato using a four-bar apparatus and reduced height growth by $26 \%$ to $35 \%$ compared with untreated control plants. Johjima et al. (1992) achieved growth reductions of $\approx 30 \%$ in six tomato lines compared with controls using a suspended steel bar for 1.5 min twice daily. The lower degree of growth inhibition during the air knife experiment (Table 3 ) might be related to the throttle valve being closed to $60^{\circ}$, resulting in a marked reduction of air velocities that ranged between 1 and $4 \mathrm{~m} \cdot \mathrm{s}^{-1}$ (Fig. 9C) compared with air velocities that were achieved with a $90^{\circ}$ throttle opening (Figs. 5B and 7). However, even with the fully opened throttle, the distance from the air outlet would need to be reduced to $50 \mathrm{~cm}$ to obtain an air velocity similar to that at $60 \mathrm{~cm}$ from the $360^{\circ}$ rotor module with the same throttle opening (Fig. 5B and C). Nevertheless, the variability in air velocities along the aperture slot is a major drawback (Fig. 7).

The predominant factor that determined the degree of growth inhibition in tomato was the stimulus intensity, resulting in a negative linear relationship between the maximum air velocities perceived $\left(1-4 \mathrm{~m} \cdot \mathrm{s}^{-1}\right)$ and plant height (Fig. 10C). Studies that have investigated the effects of various stimulation intensity are scarce. Jaffe et al. (1980) applied defined forces on tomato stems and showed that a log linear function best described the relationship between the amount of force applied and the magnitude on stem elongation. More specifically, Hunt and Jaffe (1980) found a curvilinear growth pattern for bean (Phaseolus vulgaris), with a tendency toward response saturation with $4.4 \mathrm{~m} \cdot \mathrm{s}^{-1}$ air velocity. Consequently, it is interesting to investigate whether air velocities greater than 4 $\mathrm{m} \cdot \mathrm{s}^{-1}$ of the tested modules will lead to a greater reduction in height than that found during this study.

Even with increasingly greater air velocities more than $4 \mathrm{~m} \cdot \mathrm{s}^{-1}$ of the rotor module because there was no adjustment of the distance between the air outlet and shoot tip (Fig. 5C), the growth reduction throughout the 2 -week experimental period was not greater than that achieved with a constant air velocity of $4 \mathrm{~m} \cdot \mathrm{s}^{-1}$ with the air pressure module because of the constant distance between the air outlet and plant height (Table 3 ). This plant response indicates that air velocities more than $4 \mathrm{~m} \cdot \mathrm{s}^{-1}$ do not induce greater height growth inhibition in tomato, thereby confirming the findings of Hunt and Jaffe (1980).

Garner and Björkman (1996) investigated the effect on tomato stem elongation with variable doses (10-40 strokes per day), stroke intervals (0.01-10 $\mathrm{min})$, and time of day when the treatment was applied and found no graded plant responses. This was in accordance with the results of this study, which showed that the stimulation frequency/duration is of minor importance (Fig. 10A) for an effective height control, as already suggested by Latimer (1991). Further evidence is provided by the fact that multiple air stimuli per transit were applied $(\approx 10)$ with the $360^{\circ}$ rotation of the PVC tubes attached to the rotor module but the degree of height growth inhibition was not different than that found in the air pressure and air knife module experiments, during which only one air stimulus per transit was applied. It remains to be investigated to what extent the daily treatment frequency can be reduced while maintaining the maximum degree of height control. We also found that the bending stress applied by air streams does not accumulate (Fig. 10B), indicating that plants do not integrate the mechanical stimulus over time, which has also been shown by Garner and Björkman (1996). We postulate that the response to mechanical stimulation follows an allor-nothing principle with a plant sensitivity response range between the stimulus intensity threshold and the stimulus intensity saturation point.

Commercial application. When creeping inchplants were treated 160 times per day with air streams of the air pressure module, plant height was reduced by $14 \%$ to $32 \%$, depending on the season (Fig. 10). Seasonal effects were also reported for petunia and dusty miller, which responded to a greater extent during fall compared with spring (Autio et al., 1994). Similarly, Heuchert and Mitchell (1983) found that the plant response in tomato to mechanical stimulation was greater in winter than in summer, and that lower light intensities exhibited stronger plant responses compared with higher light levels. Generally, moderate temperatures and low light levels seem to enhance plant responsiveness to mechanical stimulation (Latimer, 1991), similar to the results found during this study because no additional lighting was applied during winter and the lower room temperatures compared to those during summer. The local horticulturist was able to regulate the height of creeping inchplants throughout 1 year for five consecutive experimental sets, clearly demonstrating that this product can be organically produced at high market value without PGR applications.

\section{Conclusions}

Plant height reduction of greenhouse crops has been frequently achieved by changing temperature conditions or regulating water and nutrient supplies. PGRs are still the most commonly used method of avoiding excessive stem elongation in ornamentals, but there is growing concern regarding the use of chemicals during plant production. Stimuli applied by directed air streams were shown to be a suitable alternative to PGRs and showed efficiency comparable to that of previous techniques relying on touch or brush stimulation. The degree of responsiveness to mechanical stimulation in tomato was shown to predominantly depend on stimulus intensity. The full automation of the presented systems allows flexible and user-friendly large-scale application for horticultural companies. In the future, the dose-response relationships will help identify economically suitable application regimes and increase resource efficiency of greenhouse plant production.

\section{Literature cited}

Adler, P.R. and G.E. Wilcox. 1987. Salt stress, mechanical stress, or chlormequat chloride effects on morphology and growth recovery of hydroponic tomato transplants. J. Amer. Soc. Hort. Sci. 112:22-25.

Autio, J., I. Voipio, and T. Koivunen. 1994. Responses of aster, dusty miller, and petunia seedlings to daily exposure to mechanical stress. HortScience 29:1449-1452, doi: 10.21273/HORTSCI.29.12.1449.

Baden, S.A. and J.G. Latimer. 1992. An effective system for brushing vegetable transplants for height control. HortTechnology 2:412-414, doi: 10.21273/ HORTTECH.2.3.412. 
Beyl, C.A. and C.A. Mitchell. 1977. Automated mechanical stress application for height control of greenhouse chrysanthemum. HortScience 12:575-577.

Biddington, N.L. and A.S. Dearman. 1985. The effect of mechanically induced stress on the growth of cauliflower, lettuce and celery seedlings. Ann. Bot. 55:109-119, doi: 10.1093/oxfordjournals.aob.a086869.

Biddington, N.L. and A.S. Dearman. 1987. The effects of mechanically-induced stress and plant growth regulators on the growth of lettuce, cauliflower and bean (Phaseolus vulgaris L.) plants. Plant Growth Regulat. 5:183-194, doi: $10.1007 /$ BF00024694.

Chehab, E.W., E. Eich, and J. Braam. 2009. Thigmomorphogenesis: A complex plant response to mechano-stimulation. J. Expt. Bot. 60:43-56, doi: 10.1093/jxb/ ern315.

Garner, L.C. and T. Björkman. 1996. Mechanical conditioning for controlling excessive elongation in tomato transplants: Sensitivity to dose, frequency, and timing of brushing. J. Amer. Soc. Hort. Sci. 121:894 900, doi: 10.21273/JASHS.121.5.894.

Garner, L.C. and T. Björkman. 1997. Using impedance for mechanical conditioning of tomato transplants to control excessive stem elongation. HortScience 32:227229, doi: 10.21273/HORTSCI.32.2.227.

Garner, L. and A. Langton. 1997. Commercial adaptation of mechanical stimulation for the control of transplants growth. Acta Hort. 435:219-230, doi: 10.17660/ ActaHortic.1997.435.21.

Heuchert, J.C. and C.A. Mitchell. 1983. Inhibition of shoot growth in greenhousegrown tomato by periodic gyratory shaking. J. Amer. Soc. Hort. Sci. 108:795-800.

Hunt, E.R. and M.J. Jaffe. 1980. Thigmomorphogenesis - The interaction of wind and temperature in the field on the growth of Phaseolus vulgaris L. Ann. Bot. 45:665-672.

Jaffe, M.J. 1973. Thigmomorphogenesis: The response of plant growth and development to mechanical stimulation.
Planta 114:143-157, doi: 10.1007/ BF00387472.

Jaffe, M.J., R. Biro, and K. Bridle. 1980. Thigmomorphogenesis: Calibration of the parameters of the sensory function in beans. Physiol. Plant. 49:410-416, doi: 10.1111/j.1399-3054.1980.tb03326.x.

Jaffe, M.J. and S. Forbes. 1993. Thigmomorphogenesis: The effect of mechanical perturbation on plants. Plant Growth Regulat. 12:313-324, doi: $10.1007 /$ BF00027213.

Johjima, T., J.G. Latimer, and H. Wakita. 1992. Brushing influences transplant growth and subsequent yield of four cultivars of tomato and their hybrid lines. J. Amer. Soc. Hort. Sci. 117:384-388, doi: 10.21273/JASHS.117.3.384.

Koch, R., H. Sauer, and U. Ruttensperger. 2011. Einfluss von mechanischen Berührungsreizen auf das Wachstum von Küchenkräutern im Topf. Gesunde Pflanzen 63:199-204, doi: 10.1007/s10343011-0266-6.

Latimer, J.G., T. Johjima, and K. Harada. 1991. The effect of mechanical stress on transplant growth and subsequent yield of four cultivars of cucumber. Scientia Hort. 47:221-230, doi: 10.1016/03044238(91)90005-J.

Latimer, J.G. 1990. Drought or mechanical stress affects broccoli transplant growth and establishment but not yield. HortScience 25:1233-1235, doi: 10.21273/ HORTSCI.25.10.1233.

Latimer, J.G. 1991. Mechanical conditioning for control of growth and quality of vegetable transplants. HortScience 26: 1456-1461.

Latimer, J.G. 1992. Drought, paclobutrazol, abscisic acid, and gibberellic acid as alternatives to daminozide in tomato transplant production. J. Amer. Soc. Hort. Sci. 117:243-247, doi: 10.21273/ JASHS.117.2.243.

Latimer, J.G. 1994. Pepper transplants are excessively damaged by brushing. HortScience 29:1002-1003.
Latimer, J.G. 1998. Mechanical conditioning to control height. HortTechnology 8:529-534, doi: 10.21273/ HORTTECH.8.4.529.

Latimer, J.G. and R.B. Beverly. 1993. Mechanical conditioning of greenhousegrown transplants. HortTechnology 3: 412-414.

Latimer, J.G. and P.A. Thomas. 1991. Application of brushing for growth control of tomato transplants in a commercial setting. HortTechnology 48:109-110, doi: 10.21273/HORTTECH.1.1.109.

Morel, P., L. Crespel, G. Galopin, and B. Moulia. 2012. Effect of mechanical stimulation on the growth and branching of garden rose. Scientia Hort. 135:59-64, doi: 10.1016/j.scienta.2011.12.007.

Raviv, M. 2010. Sustainability of organic horticulture. Hort. Rev. 36:289-333, doi: 10.1002/9780470527238.ch6.

Regnant, R., R. Koch, H. Sauer, and D. Klein. 2009. Koriander im Topf Sorten, Düngung, Mechanische Reizung. ÖKOmenischer Gärtnerrundbrief $2: 18-19$.

Samimy, C. 1993. Physical impedance retards top growth of tomato transplants. HortScience 28:883-885.

Schnelle, M.A., B.D. McCraw, and T.J. Schmoll. 1994. A brushing apparatus for bedding plants. HortTechnology 4: 275-276.

Sparke, M. and J. Wünsche. 2020. Mechanosensing of plants. Hort. Rev. 47:4383, doi: 10.1002/9781119625407.ch2.

Trancossi, M. 2011. An overview of scientific and technical literature on Coanda effect applied to nozzles. SAE Technical Papers 2011-01-2591, doi: 10.4271/ 2011-01-2591.

Zawadzki, L., J. Cichoń, J. Jarzebowski, and H. Kapusta. 2010. Determination of the air velocity in the free stream flowing out of a cylindrical and two-gap skewed jet (dual slot die). Fibres Text. East. Eur. 82:39-43. 